\title{
PEMUPUKAN NPK PADA TANAMAN Eucalyptus camaldulensis Dehnh DI LAHAN SAVANA, KABUPATEN SUMBA TIMUR, PROPINSI NUSA TENGGARA TIMUR
}

\author{
NPK Fertilization on Eucalyptus camaldulensis Dehnh at Savanna Land, \\ East Sumba Regency, East Nusa Tenggara Province \\ I Komang Surata \\ Balai Penelitian Kehutanan Kupang \\ Jl. Untung Suropati No. 7, PO Box 67, Kupang 85115 \\ Telp. (0380) 823357, Fax. (0380)831068) \\ Naskah masuk : 22 Pebruari 2008 ; Naskah diterima : 4 Januari 2009
}

\begin{abstract}
Marginal soils in savanna region, Sumba island, East Nusa Tenggara (NTT) is usually deficient on macro nutrients such as N, P, and $K$. To increase the growth of Eucalyptus camaldulensis in the rehabilitation effort on degraded areas in this location is required NPK fertilizers. NPK is an anorganic complex fertilizer that contains Nitrogen, Phospate and Potassium which are known able to increase plant growth in marginal soil. The objective of the research was to find the optimum dosage of NPK fertilizer to improve E. camaldulensis growth at field plantation. The study was conducted with Completely Block Randomized Design using 4 dosages of NPK fertilizer i.e.: 0, 50, 100, $150 \mathrm{~g} /$ trees replicated 3 with 49 trees each. The result of this experiment proved that application of NPK fertilizer has significant effects to improve the survival and height, except on the diameter growth. The better survival and height of plantation was produced by application of $50 \mathrm{~g} /$ trees NPK fertilizer than the other treatment. The growth rank from the highest to lowest consecutively were $50,0,100$, and $150 \mathrm{~g} /$ trees indicated with survival rate of $67,35 \% ; 40,24 \% ; 18,36 \% ; 12,24 \%$ respectively. Supplying NPK fertilizer more than 50 g/tree caused growth lower than control.
\end{abstract}

Keywords: Eucalyptus camaldulensis Dehnh, NPK fertilization, nutrient deficiency, marginal soil

\begin{abstract}
ABSTRAK
Tanah marginal di daerah savana pulau Sumba, Propinsi Nusa Tenggara Timur (NTT) umumnya mempunyai kekurangan unsur hara makro seperti N, P, dan K. Untuk meningkatkan pertumbuhan tanaman E. camaldulensis dalam rehabilitasi lahan kritis di daerah ini diperlukan pemupukan NPK. NPK adalah pupuk kompleks anorganik yang mengandung Nitrogen (N), Phosphor (P), dan Kalium (K) yang dikenal dapat meningkatkan pertumbuhan tanaman pada tanah-tanah marginal. Penelitian bertujuan untuk mengetahui dosis optimum pemupukan NPK terhadap pertumbuhan tanaman E. camaldulensis di lapangan. Penelitian disusun dalam Rancangan Acak Kelompok dengan perlakuan 4 dosis pupuk NPK antara lain: 0, 50, 100, $150 \mathrm{~g} /$ pohon, yang terdiri 3 ulangan dengan 49 tanaman. Hasil penelitian menunjukkan bahwa pemupukan NPK nyata meningkatkan persen tumbuh dan tinggi serta tidak nyata meningkatkan diameter tanaman E. camaldulensis pada umur 15 bulan. Persen tumbuh dan tinggi tanaman yang terbaik dihasilkan dengan menggunakan konsentrasi pupuk NPK $50 \mathrm{~g} /$ pohon. Urutan persen tumbuh yang terbaik sampai terendah adalah pada perlakuan dosis : 50, 0, 100,150 g/pohon, dengan nilai masing-masing persen tumbuh 67,$35 ; 40,24 ; 18,36 ; 12,24 \%$. Pemupukan NPK lebih dari $50 \mathrm{~g} /$ pohon menyebabkan pertumbuhan tanaman lebih rendah dari pada kontrol.
\end{abstract}

Kata kunci: Eucalyptus camaldulensis Dehnh, pemupukan NPK, kekurangan unsur hara, tanah marginal 


\section{PENDAHULUAN}

Eucalyptus camaldulensis Dehnh merupakan salah satu jenis pohon penghasil kayu yang dapat tumbuh dengan baik di daerah kering dan tanah marginal di Propinsi Nusa Tenggara Timur (NTT). Jenis pohon ini termasuk eksotik asal benua Australia yang diintroduksi di NTT pada tahun 1987 untuk keperluan kegiatan penelitian uji jenis tanaman reboisasi di Balai Penelitian Kehutanan Kupang. Menurut Jacob (1981), jenis pohon ini sudah dibudidayakan di daerah tropis dan subtropik lainnya seperti India, Pakistan, Bangladesh, Srilangka, China, Malaysia, Filipina, Thailand, Nepal dan Myanmar. Perkembangan penanaman jenis pohon ini sangat pesat karena kayunya sangat laku di pasaran, termasuk jenis pohon cepat tumbuh, karakteristik terubusannya baik, toleran terhadap tanah basah, tanah kering, dan kadar garam tinggi. Jenis kayunya termasuk kuat, daya tahan baik dan tahan serangan hama serangga, dapat digunakan untuk: bantalan rel kereta api, tiang, lantai dermaga, kayu kontruksi gedung, sebagai kayu bakar, dan pulp (Eldridge,1975). Salah satu hal yang menarik dari E. camaldulensis adalah riapnya tergolong tinggi, pohonnya lurus, termasuk tanaman cepat tumbuh, daurnya pendek, mempunyai kualitas kayu yang baik dan terubusannya cepat tumbuh (Lemens dan Soerianegara, 1994).

Hasil pengujian jenis pohon ini di daerah savana, Hambala, Kabupaten Sumba Timur menunjukkan bahwa adaptabilitasnya cukup baik, yaitu pada umur 5 tahun dapat mencapai tinggi 294,52 $\mathrm{cm}$ dan diameter $2,47 \mathrm{~cm}$ akan tetapi persen tumbuhnya masih rendah yaitu $30 \%$ (Harisetijono et al., 1998). Hasil ini masih di bawah standar nilai keberhasilan reboisasi yang dipersyaratkan yaitu $80 \%$. Hasil pengamatan di lapangan juga menunjukkan terjadi gejala defisiensi unsur hara N, P yang ditandai oleh daunnya warna kuning dan ungu-kemerahan. Hal ini disebabkan karena kesuburan tanah di lokasi penanaman mempunyai kandungan C-organik, $\mathrm{P}, \mathrm{N}$, dan $\mathrm{K}$ rendah, solum tanah dangkal (jenis litosol), bahan induk batu kapur, dan tingkat pelapukan batuan rendah akibat curah hujan yang rendah (Surata, 2002).

Untuk mengatasi masalah ini maka diperlukan penambahan unsur hara yaitu melalui pemupukan sehingga dapat memacu pertumbuhan awal tanaman di lapangan. Menurut Hardjowigeno (1987) pemupukan diberikan apabila unsur hara di dalam tanah tidak mencukupi kebutuhan tanaman. Kekurangan unsur hara ini bisa diketahui melalui analisis tanah, gejala pertumbuhan tanaman, analisis tanaman, dan percobaan di lapangan. Evans (1982) menyatakan bahwa kekurangan unsur hara yang satu akan mempengaruhi penyerapan unsur hara yang lainnya, dan penyerapan unsur hara di dalam tanaman akan ditentukan oleh ketersedian unsur hara yang terendah. Hardjowigeno (1982) menyatakan bahwa sangat sedikit pengaruhnya apabila kekurangan unsur hara hanya diberikan salah satu unsur hara saja seperti $\mathrm{K}$ atau $\mathrm{P}$ saja, akan tetapi jika diberikan bersama sama $\mathrm{P}$ dan $\mathrm{K}$ atau kekurangan unsur hara yang lainnya maka akan terjadi peningkatan pertumbuhan. Dengan demikian untuk tanah marginal di daerah savana, Sumba Timur pemberian pupuk majemuk seperti NPK diduga akan menghasilkan pertumbuhan yang lebih baik. Beberapa hasil penelitian pemupukan NPK di daerah semiarid pada jenis tanah Grumusol di Oetium, Kupang menunjukkan bahwa pemupukan NPK dosis $20 \mathrm{~g}$ /pohon menghasilkan pertumbuhan tanaman E. urophylla yang paling baik pada umur 2 tahun (Effendi, 1998).

NPK adalah pupuk majemuk anorganik berupa campuran Nitrogen (N), Fosfor (P) dan Kalium (K) yang telah diformulasikan dalam bentuk granular untuk memudahkan aplikasi kepada praktisi di lapangan. Pupuk ini digunakan untuk menambah unsur hara pada tanah-tanah yang kekurangan unsur hara. Pemupukan ini ditujukan untuk mempersiapkan tanaman menjadi lebih baik dan siap untuk beradaptasi dengan kondisi lingkungan yang kurang menguntungkan dan meningkatkan pertumbuhan tanaman terutama pada tanah-tanah yang kekurangan unsur hara.

Untuk efektifitas pemanfaatan pupuk NPK penggunaannya harus diberikan pada musim hujan, sehingga dengan adanya air maka unsur hara secara fisiologis akan lebih cepat dan lebih mudah diserap akar tanaman. Adanya pelarut air pada musim hujan akan membantu proses metabolisme tanaman. Namun dalam penerapannya di lapangan diperlukan dosis yang optimal dan perhitungan pupuk yang tepat 
karena di lapangan pupuk mudah hilang akibat tercuci oleh air hujan atau menguap ke udara (seperti N). Oleh karena itu perlu diketahui dosis pupuk NPK yang optimal untuk pertumbuhan tanaman.

Berdasarkan permasalah tersebut maka dilakukan penelitian yang bertujuan untuk mengetahui pengaruh pemupukan NPK terhadap pertumbuhan E. camaldulensis. Penelitian ini juga untuk menentukan dosis maksimum pemupukan NPK pada awal penanaman di lapangan.

\section{BAHAN DAN METODE}

\section{A. Tempat dan Waktu Penelitian}

Penelitian dilakukan di Hambala, Stasiun Penelitian Kehutanan Balai Penelitian Kehutanan Kupang, Kabupaten Sumba Timur, Propinsi NTT, yang dilaksanakan pada tahun 2004 - 2006. Lokasi penelitian berada pada ketinggian $200 \mathrm{~m}$ dari permukaan laut, curah hujan rata-rata $967 \mathrm{~mm} /$ tahun termasuk tipe iklim D (Schmidt dan Ferguson, 1951) dan jenis tanah Litosol yang tersusun dari jenis batuan induk batu kapur (Pusat Penelitian Tanah dan Agroklimat, 1993).

\section{B. Bahan Penelitian}

Bahan yang digunakan dalam penelitian ini adalah:

1. Biji E. camaldulensis

2. Bahan persemaian: bak tabur dari bak plastik ukuran $40 \mathrm{~cm} \times 30 \mathrm{~cm} \times 12 \mathrm{~cm}$, media semai (tanah, pasir, kompos), kantung plastik ukuran $15 \mathrm{~cm}$ x $20 \mathrm{~cm}$, ember, kuwali, insektisida sevin, sprayer, persemaian (konvensional dengan sungkup plastik dan non konvensional dengan shade house)

3. Bahan penanaman: ajir, pupuk NPK (15-15-15) dan areal penanaman.

4. Peralatan pengamatan data: timbangan, meter roll, kaliper, phi band dan bor tanah.

\section{Metode Penelitian.}

\section{Pelaksanaan Teknis Penelitian}

Tahap pertama dari kegiatan penelitian adalah penaburan benih E. camaldulensis di bak tabur (bak kecambah) yang bagian bawahnya dilubangi. Media yang dipakai adalah pasir halus yang telah disterilkan dengan disangrai selama 10 menit. Penyiraman dilakukan setiap hari dengan mencelupkan dasar bak tabur dalam bak berisi air sampai mencapai kapasitas lapang. Bak tabur diletakkan di persemaian yang ditutup dengan sungkup atap plastik transparan. Penyiraman dilakukan dengan sprayer yang curahan airnya halus dan dilakukan secara hati-hati agar bibit tidak terangkat. Setelah bibit tumbuh setinggi $2 \mathrm{~cm}$ maka dilakukan penyapihan ke kantung plastik.

Penyapihan dilakukan dengan menggunakan kantung plastik ukuran $15 \mathrm{~cm}$ x $20 \mathrm{~cm}$ yang diisi dengan media tanam berupa campuran tanah : kompos dalam perbandingan $4: 1$. Penyapihan dilakukan di shade house. Bibit E. camaldulensis ditanam satu pohon per polibag. Sebulan sebelum dipindahkan ke lapangan dilakukan hardening off dan pemotongan akar yang tembus kantung plastik. Pada umur 6 bulan dilakukan seleksi bibit dan bibit siap ditanam di lapangan.

Penanaman dilakukan pada awal musim penghujan (Desember) pada lahan yang telah dibersihkan dari rumput dan semak, dengan jarak tanam $3 \mathrm{~m}$ x $3 \mathrm{~m}$. Pemupukan NPK dilakukan 1 bulan setelah penanaman yang diletakkan dekat lubang berbentuk lingkaran sedalam $5 \mathrm{~cm}$ yang dibuat di sekitar perakaran tanaman radius $20 \mathrm{~cm}$. Pemupukan dilakukan dengan memberikan pupuk ke dalam tanah sesuai dosis perlakuan dan diberikan sebanyak satukali. 


\section{Rancangan Penelitian}

Penelitian menggunakan Rancangan Acak Kelompok dengan perlakuan pemupukan NPK dosis : 0, 50, 100, $150 \mathrm{~g} /$ pohon. Setiap perlakuan terdiri dari 3 ulangan (kelompok), setiap kelompok terdiri dari 49 bibit. Untuk mengetahui pengaruh perlakuan maka dilakukan pengamatan tinggi, diameter, dan persen hidup. Serta pengamatan sifat fisik dan kimia tanah di lokasi penelitian.

\section{Analisis data}

Data hasil pengamatan diolah secara statistik dengan menggunakan program SPSS (Santoso, 2000). Pengaruh perlakuan yang nyata kemudian diuji lebih lanjut untuk mengetahui perbedaan antara komponen perlakuan dengan uji LSD $5 \%$. Untuk mengetahui urutan perlakuan terbaik-terendah maka dibuat rangking yang dianalisis menurut bilangan ordinasi (Good dall, 1954 dalam Wilde et al.,1979).

\section{HASIL DAN PEMBAHASAN}

\section{A. Pertumbuhan Tanaman}

Hasil analisis sidik ragam pertumbuhan tinggi, diameter, dan persen hidup tanaman $E$. camaldulensis umur 15 bulan setelah tanam disajikan pada Tabel 1. Hasil analisis menunjukkan bahwa pemupukan NPK memberikan pengaruh nyata terhadap pertumbuhan tinggi dan persen hidup tanaman dan tidak nyata terhadap pertumbuhan diameter.

Tabel (Table) 1. Analisis keragaman tinggi, diamater dan persen hidup tanaman E. camaldulensis pada umur 15 bulan (Analysis of variance for height, diameter and survival on E. camaldulensis at 15 months old)

\begin{tabular}{|c|c|c|c|c|c|c|}
\hline $\begin{array}{l}\text { Parameter } \\
\text { (Parameter) }\end{array}$ & $\begin{array}{l}\text { Sumber } \\
\text { Keragaman } \\
\text { (Source of } \\
\text { variance) }\end{array}$ & $\begin{array}{l}\mathrm{Db} \\
(\mathrm{df})\end{array}$ & $\begin{array}{c}\text { JK } \\
\text { (SS) }\end{array}$ & $\begin{array}{c}\text { KT } \\
\text { (MS) }\end{array}$ & $\mathrm{F}$ & Sig. \\
\hline $\begin{array}{l}\text { Tinggi } \\
(\text { Height })\end{array}$ & $\begin{array}{l}\text { Perlakuan } \\
\text { (Treament) } \\
\text { Blok (Block) } \\
\text { Acak (Error) }\end{array}$ & $\begin{array}{l}3 \\
2 \\
6\end{array}$ & $\begin{array}{r}5339,667 \\
958,421 \\
1139,509\end{array}$ & $\begin{array}{r}1779,889 \\
1479,210 \\
189,918\end{array}$ & $\begin{array}{l}9,372 \\
7,789\end{array}$ & $\begin{array}{l}0,011^{*} \\
0,022^{*}\end{array}$ \\
\hline & Total & 11 & 9437,597 & & & \\
\hline $\begin{array}{l}\text { Diameter } \\
\text { (Diameter) }\end{array}$ & $\begin{array}{l}\text { Perlakuan } \\
\text { (reament) } \\
\text { Blok (Block) } \\
\text { Acak (Error) }\end{array}$ & $\begin{array}{l}3 \\
2 \\
6\end{array}$ & $\begin{array}{l}1,742 \\
1,490 \\
1,461\end{array}$ & $\begin{array}{l}0,581 \\
0,745 \\
0,244\end{array}$ & $\begin{array}{l}2,384 \\
3,060\end{array}$ & $\begin{array}{l}0,168 \\
0,121\end{array}$ \\
\hline & Total & 11 & 4,694 & & & \\
\hline $\begin{array}{l}\text { Hidup } \\
\text { (Survival) }\end{array}$ & $\begin{array}{l}\text { Perlakuan } \\
\text { (Treament) } \\
\text { Blok }(\text { Block }) \\
\text { Acak }(\text { Error })\end{array}$ & $\begin{array}{l}3 \\
2 \\
6\end{array}$ & $\begin{array}{r}1884,705 \\
92,028 \\
590,396 \\
\end{array}$ & $\begin{array}{r}628,235 \\
46,014 \\
98,399 \\
\end{array}$ & $\begin{array}{l}6,385 \\
0,468\end{array}$ & $\begin{array}{c}0,027 * \\
0,648\end{array}$ \\
\hline & Total & 11 & 2567,129 & & & \\
\hline
\end{tabular}

Keterangan(Remarks): *Berbeda nyata pada taraf uji $5 \%$ (Significant on $5 \%$ level)

Selanjutnya hasil analisis Uji LSD 5 \% (Tabel 2) menunjukkan bahwa perlakuan NPK $50 \mathrm{~g}$ /pohon paling baik meningkatkan pertumbuhan tinggi dan persen hidup tanaman E. camaldulensis dibandingkan dengan dosis 0,100 dan $150 \mathrm{~g} /$ pohon. Peningkatan pertumbuhan ini disebabkan karena kandungan unsur 
hara pada lokasi penelitian masih rendah dan terjadi kekurangan unsur hara makro yang sangat dibutuhkan tanaman terutama unsur N, P, dan K (Tabel 4). Dengan adanya pemupukan NPK maka kekurangan unsur hara tersebut bisa terpenuhi untuk menopang kebutuhan pertumbuhan tanaman.

Urutan perlakuan pemupukan NPK yang terbaik sampai terendah berdasarkan analisis ordonasi, adalah berturut-turut pada perlakuan pemupukan NPK dosis : 50, 0, 100, $150 \mathrm{~g} /$ pohon (Tabel 2).

Tabel(Table) 2. Rata-rata tinggi, diameter, persen hidup dan rangking pertumbuhan tanaman E. camaldulensis umur 15 bulan (Average of height, survival, and grade on E. camaldulensis plantation at 15 months old)

\begin{tabular}{|c|c|c|c|c|c|}
\hline $\begin{array}{c}\text { Nomor } \\
\text { (Number })\end{array}$ & $\begin{array}{c}\text { Perlakuan Pupuk } \\
\text { NPK } \\
(\text { NPK Fertilizer } \\
\text { treatment }) \\
(g / \text { trees })\end{array}$ & $\begin{array}{c}\text { Tinggi } \\
(\text { Height }) \\
(\mathrm{cm})\end{array}$ & $\begin{array}{c}\text { Diameter } \\
\text { (Diameter }) \\
(\mathrm{cm})\end{array}$ & $\begin{array}{c}\text { Hidup } \\
(\text { Survival) } \\
(\%)\end{array}$ & $\begin{array}{c}\text { Rangking } \\
(\text { Grade })\end{array}$ \\
\hline 1 & $0(\mathrm{R} 0)$ & $82,43 \mathrm{a}$ & $1,768 \mathrm{a}$ & $40,24 \mathrm{ac}$ & 2 \\
\hline 2 & $50(\mathrm{R} 1)$ & $112,59 \mathrm{~b}$ & $2,104 \mathrm{a}$ & $67,35 \mathrm{~b}$ & 1 \\
\hline 3 & $100 \mathrm{R} 2)$ & $74,89 \mathrm{ac}$ & $1,181 \mathrm{a}$ & $18,36 \mathrm{ac}$ & 3 \\
\hline 4 & $150(\mathrm{R} 3)$ & $53,75 \mathrm{c}$ & $1,245 \mathrm{a}$ & $12,24 \mathrm{c}$ & 4 \\
\hline
\end{tabular}

Keterangan(Remarks): Nilai rata-rata yang diikuti oleh huruf yang sama dalam kolom yang sama tidak berbeda nyata pada taraf $5 \%$ menurut uji LSD (Mean values followed by the same letter on the same column are not significantly different based on LSD at the $5 \%$ level)

Hasil analisis regresi pertumbuhan tinggi, diameter, dan persen hidup tanaman E. camaldulensis pada umur 15 bulan setelah tanam disajikan pada Gambar 1, 2, dan 3. Nilai korelasi pertumbuhan tinggi, persen hidup,dan diameter dengan dosis pemupukan NPK $>0,70$. Hal ini menunjukkan adanya tingkat hubungan yang tinggi diantara parameter tinggi, diameter, dan persen hidup dengan perlakuan pemupukan (Young, 1982 dalam Sulaiman 2004).

Pada Gambar 1, 2, dan 3 terlihat bahwa hubungan antara tinggi, dan dosis pemupukan NPK menghasilkan persamaan regresi $Y=86,6510+0,52202 X-0,0051 X^{2}\left(R^{2}=0,8941\right)$, dengan pertumbuhan tinggi maksimum 99,24 cm yang dicapai adalah pada pemupukan NPK $50 \mathrm{~g} /$ pohon. Hubungan regresi antara persen hidup dan dosis pemupukan NPK menghasilkan persamaan regresi $Y=46,1885+$ $0,2325 \mathrm{X}-0,0033 \mathrm{X}^{2}\left(\mathrm{R}^{2}=0,7881\right)$ dengan persen hidup maksimum $50 \%$ dicapai pada pemupukan NPK $82 \mathrm{~g} /$ pohon. Sedangkan pertumbuhan diameter terjadi penurunan dengan adanya perlakuan pemupukan NPK dengan persamaan regresi $Y=1,8803 \quad 0,0009 X-2,7200.10^{-5} \mathrm{X}^{2}\left(\mathrm{R}^{2}=0,75236\right)$.

Berdasarkan persamaan analisis regresi tinggi, diameter dan persen hidup serta dengan mengambil dosis pemupukan NPK dari hasil nilai maksimum tinggi pada dosis $50 \mathrm{~g} /$ pohon dan persen hidup maksimum pada dosis $82 \mathrm{~g}$ /pohon maka diperoleh nilai tinggi, persen hidup dan diameter (Tabel 3). Berdasarkan analisis bilangan ordonasi maka urutan perlakuan pemupukan NPK yang terbaik sampai terendah adalah pada dosis NPK $50 \mathrm{~g} /$ pohon dan kemudian disusul pada dosis NPK $82 \mathrm{~g} /$ pohon. Dengan demikian pemupukan NPK $50 \mathrm{~g}$ /pohon menghasilkan pertumbuhan tinggi, diameter dan persen hidup yang terbaik. Pemupukan NPK di atas $50 \mathrm{~g} /$ pohon sudah menghambat pertumbuhan tanaman E. camaldulensis, yang berarti bahwa pemberian pupuk di atas dosis tersebut sudah terlalu besar dan melebihi dosis maksimum bagi pertumbuhan tanaman sehingga merusak atau meracuni tanaman. 
Tabel(Table) 3. Rangking pertumbuhan berdasarkan nilai ordinasi persamaan regresi tinggi, diameter, dan hidup hidup tanaman E. camaldulensis umur 15 bulan (Growth grade of height, diameter and survival of regression equation on $\mathrm{E}$. camaldulensis plantation at 15 months old)

\begin{tabular}{|c|c|c|c|c|c|}
\hline $\begin{array}{c}\text { Nomor } \\
\text { (Number })\end{array}$ & $\begin{array}{c}\text { Perlakuan Pupuk } \\
\text { NPK } \\
(\text { NPK Fertilizer } \\
\text { treatment }) \\
(\text { g/trees })\end{array}$ & $\begin{array}{c}\text { Tinggi } \\
(\text { Height }) \\
(\mathrm{cm})\end{array}$ & $\begin{array}{c}\text { Diameter } \\
\text { (Diameter) } \\
(\mathrm{cm})\end{array}$ & $\begin{array}{c}\text { Persen Hidup } \\
\text { (Survival) } \\
(\%)\end{array}$ & $\begin{array}{c}\text { Rangking } \\
\text { (Grade) }\end{array}$ \\
\hline 1 & 50 & 99,24 & 1,7637 & 49,46 & 1 \\
\hline 2 & 82 & 95,16 & 1,6239 & 49,51 & 2 \\
\hline
\end{tabular}

De La Cruz (1982) berpendapat bahwa penambahan hara yang berlebihan dapat bersifat racun yang menghambat pertumbuhan tanaman. Kelebihan hara pada media tanam yang melebihi kebutuhan optimum tanaman akan menyebabkan terganggunya sistem metabolisme dan rusaknya sistem enzim, sehingga menghambat pengambilan unsur hara oleh akar dan terhambatnya pertumbuhan tanaman. Menurut Sabarnudin (1980) pemupukan berat pada tanaman menyebabkan konsentrasi garam cukup tinggi di dalam tanah dan bersifat merusak tanaman. Kerusakan tersebut terjadi melalui proses plasmolisa dan besarnya kerusakan tergantung pada spesies tertentu. Hardjowigeno (1987) menyatakan bahwa kelebihan unsur hara N, P dan K di dalam tanah dapat mengakibatan berkurangnya ketersediaan unsur $\mathrm{Zn}, \mathrm{Fe}$, dan $\mathrm{Cu}$ berkurang serta mempersulit penyerapan unsur Mn.

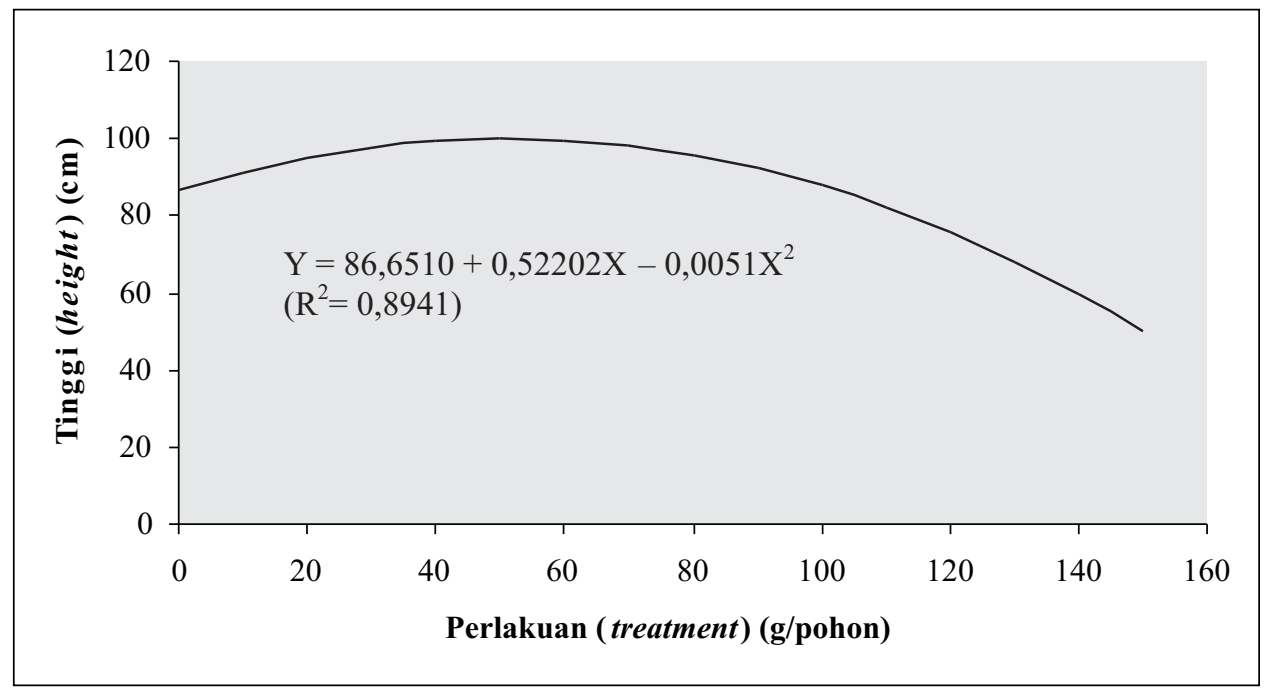

Gambar(Figure)1. Pengaruh pemupukan NPK terhadap tinggi tanaman E. camaldulensis umur 15 bulan setelah tanam (The effect of NPK fertilization on height of $\mathrm{E}$. camaldulensis plantation at 15 months after planting) 


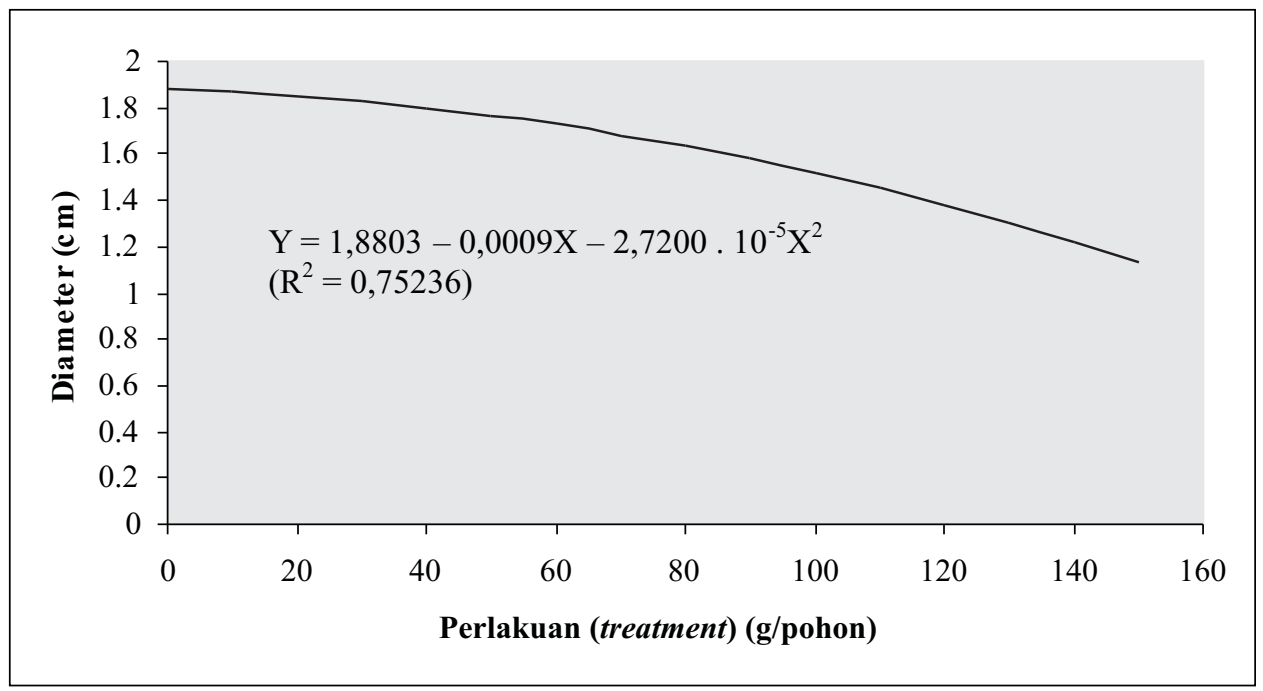

Gambar(Figure) 2. Pengaruh pemupukan NPK terhadap diameter tanaman E. camaldulensis umur 15 bulan setelah tanam (The effect of NPK fertilization on diameter of E. camaldulensis plantation at 15 months after planting)

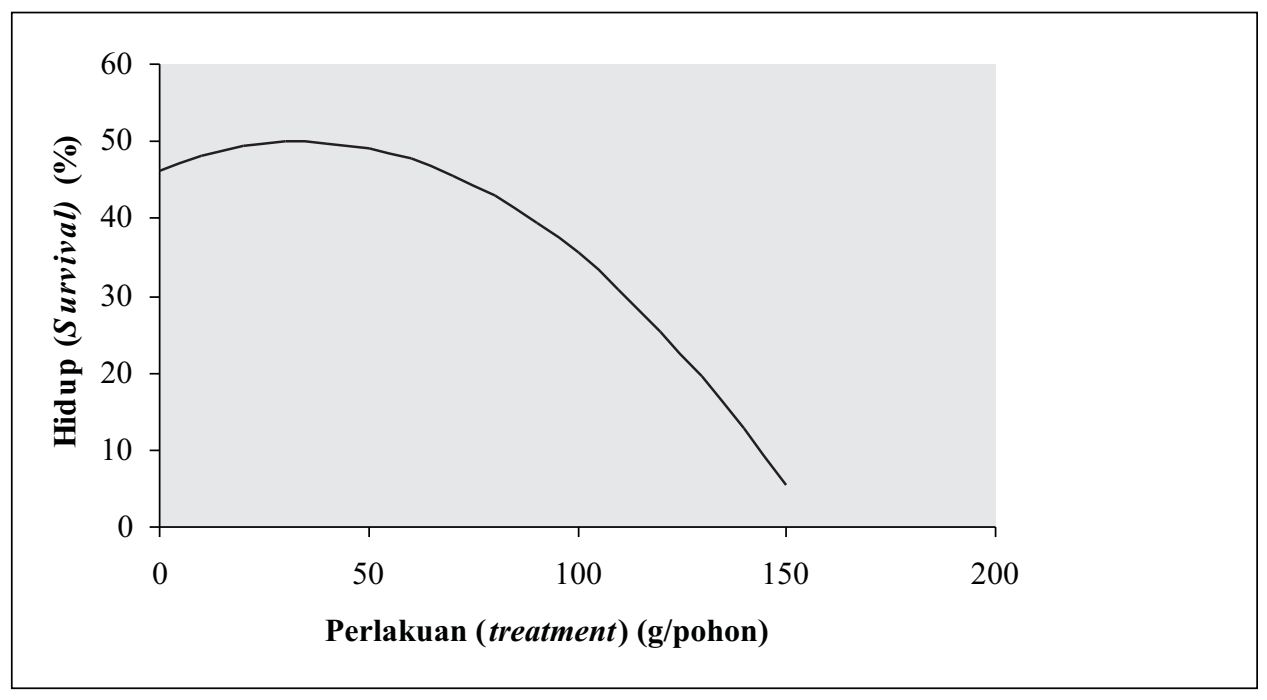

Gambar(Figure) 3. Pengaruh pemupukan NPK terhadap persen hidup tanaman E. camaldulensis umur 15 bulan setelah tanam (The effect of NPK fertilization on the survival of $E$. camaldulensis plantation at 15 months after planting)

Pemupukan NPK di Hambala, Sumba Timur memberikan respon yang baik terhadap pertumbuhan tanaman E.camaldulensis. Adanya respon pertumbuhan yang baik ini disebabkan karena jenis tanah di lokasi penelitian mempunyai kesuburan yang rendah dan disisi lain tanaman E. camaldulensis sangat membutuhkan unsur hara NPK untuk memenuhi kebutuhan untuk membantu pertumbuhannya (Tabel 4). Menurut Hardjowigeno (1987) unsur hara N, P dan K sangat dibutuhkan oleh tanaman karena unsur hara tersebut berfungsi antara lain sebagai: unsur $\mathrm{N}$ untuk memperbaiki pertumbuhan vegetatif tanaman (tanaman yang tumbuh cukup $\mathrm{N}$ akan berwarna lebih hijau), pembentukan protein, unsur P untuk pembentukan sel, perkembangan akar, metabolisme karbohidrat, pemeliharaan pengaktifan struktur dan unsur $\mathrm{K}$ untuk pembentukan pati, enzim, pembukaan stomata, proses fisiologi tanaman, proses metabolik dalam sel, mempengaruhi penyerapan unsur lain, perkembangan akar, dan mempertinggi daya tahan terhadap kekeringan. 
Pemupukan NPK $50 \mathrm{~g} /$ pohon menghasilkan pertumbuhan yang terbaik yaitu dengan meningkatkan pertumbuhan tinggi, persen hidup masing-masing: 99,24 $\mathrm{cm}, 49,46 \%$ atau dapat meningkatkan pertumbuhan tinggi, dan persen hidup masing masing 20,39\%, 24,25\% akan tetapi menurunkan pertumbuhan diameter $1,7637 \mathrm{~cm}$ atau $0,24 \%$ terhadap kontrol. Persen tumbuh ini lebih baik dari hasil pengujian E. camaldulensis di lokasi yang sama yang menghasilkan persen tumbuh $30 \%$ pada umur 5 tahun (Harisetijono et al., 1998). Beberapa hasil pemupukan E. camaldulensis di Filipina memberikan respon yang lebih baik pada level P $30 \mathrm{~g} /$ pohon, $\mathrm{N} 30 \mathrm{~g} /$ pohon yang diberikan 3 bulan setelah tanam (Jacobs, 1981). Di Brazilia aplikasi pemupukan NPK pada Eucalyptus menggunakan dosis $50 \mathrm{~g} /$ pohon, sedangkan di Afrika menggunakan dosis $150 \mathrm{~g} /$ pohon (Evans, 1982).

Unsur hara yang dibutuhkan oleh tanaman kehutanan lebih rendah dibandingkan tanaman pangan atau perkebunan, karena berbagai alasan antara lain: tanaman kehutanan pertumbuhannya lambat, rotasinya jangka panjang dan pemupukan dalam jangka panjang tidak ekonomis. Oleh karena itu pemupukan biasanya hanya pada awal penanaman saja untuk memacu pertumbuhan awal agar persen tumbuhnya lebih baik sehingga tanaman lebih cepat beradaptasi dengan kondisi lingkungannya. Untuk pertimbangan ekonomis biasanya digunakan teknik uji species yaitu untuk memilih spesies yang dapat tumbuh dengan baik di daerah setempat (Evans,1982).

\section{B. Kesuburan Tanah}

Hasil analisis sifat fisik dan kimia tanah disajikan pada Tabel 4. Hasil analisis tekstur tanah di lokasi penelitian menunjukkan tekstur tanah termasuk liat berdebu dengan komposisi liat 49,95\%, debu 22,58 \%, dan pasir 18,15\%. Tekstur tanah menunjukkan pembagian butir-butir tanah. Butir-butir yang paling kecil adalah butir liat kemudian diikuti oleh yang lebih kasar yaitu butir debu dan pasir. Tekstur tanah yang baik adalah apabila komposisi antara pasir, debu, dan liat hampir seimbang. Dengan demikian sifat fisik tekstur tanah di lokasi penanaman termasuk halus. Semakin halus tekstur tanah berarti tanah semakin kuat memegang air dan unsur hara dan akan sulit diolah. Apabila basah akan menjadi lengket dan sulit melewatkan air hujan dan aerasi tanah kurang memberikan kondisi yang baik bagi sirkulasi udara dan air tanah di dalam pori-pori tanah. Akan tetapi karena jenis tanah ini litosol dan bahan induknya dangkal yang terdiri dari batu kapur yang porus, maka sirkulasi aerasi tanah ini masih bisa berjalan dengan baik.

Hasil analisis sifat kimia tanah disajikan pada Tabel 4. Penilaian sifat kimia tanah dengan menggunakan standar penilaian Pusat Penelitian Tanah (1983) menunjukkan bahwa pH tanah termasuk alkalis ( $\mathrm{pH} \mathrm{H} 2 \mathrm{O}$ 7,7- 7,9). Pada kondisi $\mathrm{pH}$ seperti ini akan mengurangi ketersediaan unsur hara makro $\mathrm{P}$ dan unsur hara mikro $\mathrm{Fe}, \mathrm{Mn}, \mathrm{Zn} \mathrm{Cu}$, Co di dalam tanah karena terjerap oleh koloid tanah. Demikian pula ketersediaan unsur hara makro lainnya seperti N, K, dan C-organik di lokasi penelitian termasuk rendah. Unsur hara ini termasuk unsur makro yang dibutuhkan lebih banyak oleh tanaman untuk proses pertumbuhannya. Oleh karena itu untuk meningkatkan pertumbuhan tanaman di daerah ini diperlukan masukan kekurangan unsur hara melalui pemupukan. 
Tabel 4 (Table). Hasil analisis sifat kimia dan fisik tanah penanaman (Chemical and physical analysis of plantation soil)

\begin{tabular}{|c|c|c|c|}
\hline $\begin{array}{c}\text { Karakteristik tanah } \\
\text { (Soil characteristics) }\end{array}$ & \multicolumn{2}{|c|}{$\begin{array}{l}\text { Nilai } \\
\text { (Value) }\end{array}$} & $\begin{array}{c}\text { Status *) } \\
(\text { Status })\end{array}$ \\
\hline \multirow[b]{2}{*}{ PH H2O ( $1: 1)$} & $0-18 \mathrm{~cm}$ & $18-30 \mathrm{~cm}$ & \multirow[b]{2}{*}{ Basa } \\
\hline & 7,7 & 7,9 & \\
\hline $\mathrm{PH} \mathrm{KCl}(1: 1)$ & 6,7 & 6,9 & Basa \\
\hline C-Organik (\%) & 1,7 & 1,0 & Rendah \\
\hline N-total (\%) & 0,15 & 0,10 & Rendah \\
\hline $\mathrm{C} / \mathrm{N}$ & 12 & 10 & Rendah \\
\hline P Bray-1 (ppm) & 7,0 & 1,0 & Rendah \\
\hline K-dd (me/100 g) & 0,35 & 0,09 & Rendah \\
\hline Ca-dd (me/100 g) & 40,60 & 44,17 & Tinggi \\
\hline Mg-dd (me/100 g) & 0,30 & 0,31 & Rendah \\
\hline Na-dd (me/100 g) & 0,13 & 0,16 & Rendah \\
\hline H-dd (mel/100 g) & 0,44 & 0,31 & Rendah \\
\hline Al-dd $(\mathrm{ml} / 100 \mathrm{~g})$ & $\mathrm{Tu}$ & $\mathrm{Tu}$ & \\
\hline Tekstur & - & & Liat berdebu \\
\hline Pasir (sand) (\%) & 18,15 & 29,28 & \\
\hline Debu (silt) (\%) & 22,58 & 23,20 & \\
\hline Liat (clay) (\%) & 49,95 & 46,99 & \\
\hline
\end{tabular}

*) Menurut kriteria Pusat Penelitian Tanah, Bogor (According to criteria of Research Soil Centre, Bogor) (Hardjowigeno, 1993)

\section{KESIMPULAN DAN SARAN}

\section{A. Kesimpulan}

1. Pemupukan NPK secara nyata meningkatkan pertumbuhan tinggi dan persen hidup serta tidak secara nyata meningkatkan diameter tanaman $E$. camaldulensis.

2. Pemupukan NPK 50 g/pohon paling baik meningkatkan pertumbuhan tinggi (sebesar 20,39\%) dan persen hidup tanaman $(24,25 \%)$ dan menurunkan diameter sebesar $0,24 \%$.

3. Pemupukan NPK lebih dari $50 \mathrm{~g} /$ pohon menyebabkan pertumbuhan tinggi, diameter dan persen hidup tanaman menurun dan sudah meracuni tanaman.

4. Urutan rangking pertumbuhan semai ampupu yang paling baik sampai terendah menurut bilangan ordinasi adalah berturut-turut pada perlakuan dosis 50, 0, 100 dan $150 \mathrm{~g}$ NPK dengan persen tumbuh masing-masing 67,$35 ; 40,24 ; 18,36$; dan $12,24 \%$.

5. Tanah di lokasi penelitian mempunyai tekstur liat berdebu, $\mathrm{pH}$ alkalis dan mempunyai kandungan unsur hara $\mathrm{P}, \mathrm{N}$, dan C-Organik rendah. Oleh karena itu untuk meningkatkan pertumbuhan tanaman E. camaldulensis di lokasi ini diperlukan penambahan pupuk. 


\section{B. Saran}

1. Untuk memperoleh pertumbuhan yang baik, maka untuk penanaman jenis pohon E. camaldulensis di daerah savanna Sumba Timur perlu dilakukan pemupukan NPK sebanyak 50 g/pohon yang diberikan pada awal penanaman untuk menambah kekurangan unsur hara tanah.

2. Mengingat di lokasi penelitian mempunyai iklim kering yang panjang maka pemberian pupuk perlu dilakukan pada musim penghujan, sehingga penyerapan unsur hara oleh tanaman bisa berjalan dengan baik.

\section{DAFTAR PUSTAKA}

De La Cruz. R. E. 1982. Tree Nutrition and Fertilization. Lecture Presented during Training Course in Biological Aspect of Silviculture. Biotrop, Bogor.

Evans, J. 1982. Plantation Forestry in the Tropics. Oxford University Press. New York.

Effendi, M. 1998. Uji Coba Pemupukan NPK pada Tanaman Ampupu (E. urophylla) di Daerah Tropika Semi Arid Jenis Tanah Grumusol. Buletin Penelitian Kehutanan Vol. 3.No.2. 1-9

Eldridge., K.G., 1975. Eucalyptus camaldulensis. Tropical Forestry Papers. No.8. CSIRO, Division of Forestry Research, Canberra. 59 pp.

Gardener, F.P., R.B. Peace, and R.L.Mitchell. 1985. Physiology of Crop Plants. The Iowa State University Press. USA.

Jacob, M. R. 1981. Eucalyptus for Planting, $2^{\text {nd }}$ ed. FAO Forestry. Seri 15. No.11, FAO, Rome. Italy.

Hardjowigeno, S. 1987. Ilmu Tanah. Medyatama Sarana Prakarsa. Jakarta.

Lemmens, R. H. M. J. and I. Soerianegara . 1994. Plant Resources of South-East Asia. Timber Trees: Major Commercial Timbers. No. 5 (1).PROSEA. Bogor .Indonesia.

Harisetijono, M. Sinaga, D. Setijadi. 1998. Upaya Peningkatan Produktivitas Tanaman dalam Reboisasi Savana Sumba Timur. Prosiding Espose/Diskusi Hasil Penelitian. Balai Penelitian Kehutanan Kupang. Kupang 6 Oktober 1997.

Pusat Penelitian Tanah. 1983. Klasifikasi Kesesuaian Lahan. Pusat Penelitian Tanah, Badan Litbang Pertanian Bogor.

Pusat Penelitian Tanah dan Agroklimat.1993. Peta Tanah Propinsi Nusa Tenggara Timur. Pusat Penelitian Tanah dan Agroklimat. Badan Penelitian dan Pengembangan Pertanian. Bogor.

Sabarnudin, S. 1980. Physiologi Pohon.Yayasan Pembina Fakultas Kehutanan. Universitas Gadjah Mada. Yogyakarta.

Santoso, S. 2000. SPSS Statistik Parametrik. PT. Elex Media Komputindo. Kelompok Gramedia. Jakarta.

Schmidt, F. G.and J. H. A. Ferguson .1951. Rainfall Types Based on Wet and Dry Period Ratios for Indonesia with Western New Guinea. Verhand 42. Direktorat Meteorologi dan Geofisika. Djakarta.

Surata, I. K. 2002. Pengujian Pohon Reboisasi di Daerah Savana Sumba Timur Nusa Tenggara Timur. Buletin Penelitian Kehutanan. Vol.6 No2. 1-10

Sulaiman, W. 2004. Analisis Regresi Menggunakan SPSS. Contoh Kasus dan Pemecahannya. Andi. Yogyakarta

Wilde,S. A., R. B. Corey., J. G. Iyer., and G. K.Voight. 1979. Soil and Plant Analysis for Tree Culture. Fith Revised ed., Oxford and IBH Publishing Co. 